\title{
Training in the prevention of emotional stress as a condition of psychological readiness for the profession of a teacher
}

\author{
Olga Vasilevna Shurygina ${ }^{1 *}$, Olga Petrovna Koroleva $^{2}$, Marina Vladimirovna Lebedeva ${ }^{2}$, \\ and Tatyana Konstantinovna Belyaeva ${ }^{3}$ \\ ${ }^{1}$ Nizhny Novgorod Dobrolyubov State Linguistics University, Higher School of Translation, Chair of \\ Interpreting and Translation (German language), Nizhny Novgorod, Russia \\ ${ }^{2}$ Nizhny Novgorod Dobrolyubov State Linguistics University, Higher School of Translation, Nizhny \\ Novgorod, Russia \\ ${ }^{3}$ Nizhny Novgorod State Pedagogical University named after Kozma Minin (Mininsky University), \\ Department of General and social pedagogy, Nizhny Novgorod, Russia
}

\begin{abstract}
One of the factors that negatively affect psychological readiness for the profession of a teacher is emotional stress. The article examines the definition and approaches to the description of stress, proves the relevance of the problem of teaching students training to become teachers the methods and ways of preventing and correcting stress, improving stress resistance, and preventing emotional burnout in professional activity, the methods of emotional stress prevention are analyzed. The purpose of the article is to study the method of sound therapy (neuroacoustics) and to analyze the effect of a neuroacoustic program in increasing stress resistance in students future teachers. To test the hypothesis on the influence of neuroacoustic program on the increase of stress tolerance in students training to become teachers, the authors conduct a study using the Perceived Stress Scale by S. Cohen and G. Williamson at the ascertaining and control stages and deploying the developed neuroacoustic program at the formative stage. The conducted study allows to determine and prove that the mastery of neuroacoustic methods increases stress resistance in students training to become teachers. Constant overload, disruptive student behavior, and increased demands are the causes of emotional stress in teachers. The presented method teaches future specialists to cope with stress factors in professional pedagogical activity, allows them to resist emotional and professional burnout, and thereby creates optimal conditions for psychological readiness for the profession of a teacher. The technique can be used in organizations of secondary and higher education.
\end{abstract}

Keywords: professional development, psychological readiness for the profession of a teacher, prevention of emotional stress, stress resistance.

\footnotetext{
*Corresponding author: olga_schurigina@mail.ru
} 


\section{Introduction}

Professional personality development is a long way of learning, enrichment of knowledge, development of professional skills, constant work on oneself in terms of developing professional competencies and professional personal qualities.

Psychological readiness for the profession of a teacher comprises several stages, the passage of which ensures the formation of the professional personality of a teacher: the formation of psychological readiness to choose the profession of a teacher, the formation of psychological readiness to master the profession of a teacher, and the formation of psychological readiness for self-realization in the profession of a teacher [1].

The professional development of a teacher's personality is contingent on many factors and conditions that positively and negatively affect this process.

Positive factors in the development of professional personality include both psychological readiness for the choice of profession of a teacher, and cognitive and creative activity of a future teacher that manifests in learning, research, and creative extracurricular activities of students in the learning process, etc. [1].

However, there also are negative factors that prevent the formation of adequate psychological readiness for the profession of a teacher or inhibit this process. One of the negative factors in the formation of psychological readiness for the profession of a teacher is emotional stress.

\section{Literature review}

There are different approaches to the description of stress, for instance, the physiological approach (Walter B. Kennon, H. Selye, R. Sapolsky, etc.) in which stress is considered as a reaction that occurs when the body is exposed to a threatening stimulus [2-4].

The specific characteristic of emotional stress is that both external stimuli and personal stressors can serve as the factors provoking a stress reaction. What Gert Kaluza attributes to the external factors is high workload, the lack of time to perform certain tasks, increased professional demands, obstacles to the achievement of certain goals and objectives, or pressure exerted from the outside [5]. Personal stressors, according to researchers, include impatience, personal anxiety, inadequate self-esteem, overexertion, the desire to have time for everything and keep everything under control, and excessive perfectionism [6-10].

Teachers are more subject to the influence of emotional stress. Foreign researchers Collie, Shapka, and Perry distinguish the emotional stress of a teacher and describe this state as an experience of negative emotions caused by professional activity [7]. The work of a teacher is included in the group of professions with a large number of stress factors.

External stress factors in the teaching profession include stressful psycho-emotional activities, the need to communicate with a large number of people, disruptive student behavior, the lack of autonomy, low social status, problems and conflicts in teamwork, etc. $[9,10]$

Internal stress factors include the inability to adapt, a tendency to emotional rigidity and intensive perception and experience, a tendency to strong emotional feelings even for minor reasons, etc. $[9,10]$.

Beginner teachers are especially susceptible to stress factors. Another negative factor of chronic teacher stress indicated by E.B. Dunaevskaia and S.A. Kotova is a decrease in the life-meaning content of personality and the reduction of leisure time in a teacher's life [11].

The data obtained by the Scientific Research Institute of Occupational Medicine confirm that about $60 \%$ of teachers are prone to neurosis related to professional activity [11]. This statistic accentuates the urgency of the problem of teaching future teachers the methods and 
ways to prevent and correct stress, increase stress resistance, and prevent emotional burnout in professional activity [11-13].

It is extremely important to teach students training to become teachers the methods of preventing emotional stress from the very first stages of professional development since the prevention of emotional stress is one of the conditions of psychological readiness for the profession of a teacher.

\section{Materials and methods}

In previous articles, we explored some effective methods for the prevention and psychological correction of emotional stress: Kh. Aliev's "Key" method of teaching transgenic automatic monotonous movements [8], the wingwave method of bilateral stimulation of the functional activity of the cerebral hemispheres (simulation of the REM sleep phase), F. Shapiro's method of desensitization and processing of psychological traumas through eye movements, psychological training and its role in optimizing the psychoemotional state of teachers [12], and neurobics as a method for the optimization of students' psycho-emotional state [14]. The listed methods show effective results in the reduction of the level of emotional burnout: ALPeg $=2.28$ vs. 1.78 before the psychocorrection program, $\mathrm{p} \leq 0.01[8]$.

In the present article, we analyze the effectiveness of sound therapy or neuroacoustics as a method of preventing emotional stress among students training to become future teachers.

Neuroacoustics studies the effects of sound on the human body, primarily on the brain. It has been proven that stimulation of the brain with delta frequencies (from $0 \mathrm{~Hz}$ to $4 \mathrm{~Hz}$ (cycles per second)) improves sleep quality in $98 \%$ of cases, exposure to $9.5 \mathrm{~Hz}$ increases heart rate variability, improves cardiovascular function, and prolongs life [15].

Neuroacoustic programs can improve the human condition, relieve stress, improve sleep and immune and cardiovascular systems, enhance concentration and cognitive abilities. For this purpose, the programs deploy the mechanisms of stimulation of beta-alpha-theta-delta and gamma-band waves. People with well-expressed gamma rhythms have an improved ability to solve problems, a higher level of self-control, and increased intelligence. Delta rhythms have a strong influence on regeneration and recovery of the body, stimulate the production of various hormones, promote better sleep, improve the immune system, as well as better the psycho-emotional state [15].

We hypothesize that the mastery of neuroacoustic programs would increase stress tolerance in future teachers, as well as teach them how to cope with stressors in future professional teaching activities.

To reach the study goal and test the hypothesis, we developed a neuroacoustic program based on the provisions of L. Rossolovsky and implemented it in the educational process [15].

The study was conducted in the Nizhny Novgorod Dobrolyubov State Linguistic University in 2019-2020. The experimental data were obtained as a result of diagnostics and formative work with 90 1st year students in pedagogy: 50 students made up the control group (CG) and did not participate in the neuroacoustics program and 40 students made up the experimental group (EG) and participated in the formative program.

To prove the proposed hypothesis, the Perceived Stress Scale by S. Cohen and G. Williamson was used as a psychodiagniostic method at the ascertaining and control stages of the study. 


\section{Results}

The analysis of the results of the ascertaining stage of the study shows that all students in the experimental group had an average (50\%) and low (40\%) level of stress resistance which confirmed the need for special targeted work on the prevention of emotional stress and the formation of stress resistance of students training to become teachers.

During the formative stage, we developed and tested a neuroacoustic program aimed at the prevention of emotional stress for participants in the experimental group. Daily, students of the experimental group listened to an online program at home. The deployed program has a general tonic effect on the body, relieves stress, fear, and negativity, fills a person with energy, has a strong antidepressant effect, helps to achieve a state of harmony, and raises the mood.

The dynamics of stress resistance development in the experimental group of students are studied through control diagnostics. Table 1 shows the results for the experimental group before and after the formative experiment. The results of the control group are not presented since no changes are found in the average levels of indicators.

Table 1. Diagnostic results on stress resistance in the EG before and after the formative experiment $\left(\mathrm{N}_{\mathrm{E}}=40, \mathrm{ALP}, \mathrm{p}\right)$

\begin{tabular}{|l|c|c|}
\hline \multicolumn{1}{|c|}{ Indicators } & \multicolumn{2}{|c|}{ APL } \\
\cline { 2 - 3 } & Before & After \\
\hline Stress resistance & 1.47 & $2.65^{*}$ \\
\hline Significance of differences according to Fisher's $\phi^{*}$ test: ${ }^{*}-\mathrm{p} \leq 0.01$ \\
\hline
\end{tabular}

Analysis of the data shown in Table 1 demonstrates positive changes in the stress tolerance index.

While at the ascertaining stage, the students of the studied sample had stress resistance at the level below average (average level index 1.47), at the control stage, the average level indexes reach the average level (2.65). After the neuroacoustic program, the students in the experimental group cope with stressful situations more easily. Thus, the formative work conducted with the experimental group of students has a positive effect in terms of emotional stress prevention. This work requires further continuation and research.

\section{Conclusion}

The conducted study proves that the mastery of psychological technologies, specifically Kh. Aliev's "Key" method, neurobics methods, training technologies, and neuroacoustic methods, increases stress resistance in students training to become teachers, as well as teaches them to cope with stress factors in professional pedagogical activity, allows them to resist emotional and professional burnout, and thereby creates optimal conditions for psychological readiness for the profession of a teacher.

\section{References}

1. G.V. Sorokoumova, Chelyabinsk State Pedagogical University Bulletin, 3, 175-187 (2010)

2. H. Selye, Stress bez distressa [Stress without Distress] (Progress, Moscow, 1982)

3. R. Sapolsky, Psikhologiia stressa [The Psychology of Stress] (Piter, Saint Petersburg, 2020) 
4. M.A. Odintsova, N.L. Zakharova, Psikhologiia stressa: uchebnik i praktikum dlia vuzov [Psychology of stress: a textbook and practical workbook for universities] (Iurait Publishing House, Moscow, 2020)

5. G. Kaluza, Stressbewältigung. Trainingsmanual zur pszchologischen Gesundheitsförderung [Coping with stress. Training manual for psychological health promotion] (Springer Verlag Berlin Heidelberg, Berlin, 2011)

6. E.V. Smirnova, O.V. Shurygina, Reguliatsiia emotsionalnykh sostoianii: sniatie napriazheniia pered publichnym vystupleniem [Regulation of emotional states: relieving tension before public speaking], in Proceedings of the Scientific Congress of the 20th International Scientific and Industrial Forum Velikie reki. In 3 volumes, 225227 (2018)

7. R. J. Collie, J. D. Shapka, N. E. Perry, Journal of Educational Psychology, 104, 11891204 (2012). http://dx.doi.org/10.1037/a0029356

8. G.V. Sorokoumova, O.V. Shurygina, Perm University Bulletin, 437-443 (2017)

9. R. Harmsen, M. Helms-Lorenz, R. Maulana, K. van Veen, Teachers and Teaching: Theory and Practice, 24(6), 626-643 (2018). https://doi.org/10.1080/13540602.2018.1465404

10. E. M. Skaalvik, S. Skaalvik, International Education Studies, 8, 181-192 (2015). http://dx.doi.org/10.2466/14.02.PR0.114k14w0

11. E. B. Dunaevskaia, S. A. Kotova, Bulletin of N.F. Katanov Khakass State University, 9, 43-45 (2014)

12. E.A. Vasilevskaia, Psikhologicheskaia podderzhka pedagogov v sostoianii emotsionalnogo vygoraniia [Psychological support for teachers with emotional burnout]: Ph.D. dissertation summary (Volga State Social and Humanitarian Academy, Samara, 2015). Accessed on: October 12, 2020. [Online]. Available: https://www.dissercat.com/content/psikhologicheskaya-podderzhka-pedagogov-vsostoyanii-emotsionalnogo-vygoraniya

13. B.A. Gunuzunova, Bulletin of Kemerovo State University, 2, 76-80 (2016)

14. N.V. Naumova, Spkolnaia Pedagogika, 2(5), 42-45 (2016)

15. Advanced Mind Institute, Neiroakustika - nauka budushchego [Neuroacoustics - the science of the future] (n.d.). Accessed on: September 9, 2020. [Online]. Available: https://www.advanced-mind-institute.org/articles/neiroakustika-nauka-buduschego/ 